Check for updates

The BMJ

Cite this as: BMJ 2021;372:n566 http://dx.doi.org/10.1136/bmj.n566 Published: 25 February 2021

\title{
Covid-19: Judge caps costs that campaigners will have to pay for PPE court action
}

Clare Dyer

Campaigners taking the UK government to the High Court over the award of huge contracts for personal protective equipment (PPE) without advertisement or competition have won a court order capping the costs they will have to pay if they lose.

The non-profit organisation Good Law Project and the campaigning group EveryDoctor are challenging the award of contracts to Pestfix, a pest control company; Ayanda, a private fund owned through a tax haven; and Clandeboye, a confectionary wholesaler. The case is due to be heard in May.

In the English legal system, the loser in a court case usually has to pay the other side's costs. The government told the court that its costs would probably reach £1m (€1.2m; $\$ 1.4 \mathrm{~m})$, an unusually high figure for a judicial review case.

The two groups, which rely on crowdfunding, asked the judge, Mrs Justice O'Farrell, to cap their costs liability at $£ 100$ ooo, arguing that potential costs of Ł1m would prevent them from bringing a public interest case. She agreed to make the capping order but opted for a figure of £250 ooo.

"All citizens are likely to have an interest in whether or not the procurement on the part of the government is done using good governance procedures and integrity," she said. "And therefore there is a real wider public interest that has been represented by the claimant group, which is a not-for-profit group, in bringing this challenge."

Julia Patterson, chief executive of EveryDoctor, said, "We won't be intimidated into dropping legal cases against the health secretary. Healthcare workers have endured a horrific year, and many NHS workers were provided with inadequate or unusable PPE because of decisions made by this government. Every healthcare worker who has been stranded without adequate lifesaving PPE deserves answers. We need to hold the health secretary to account."

The decision comes just a few days after a High Court judge ruled that the government acted unlawfully in failing to publish details of contracts awarded without competition, as required by law. ${ }^{1}$ The National Audit Office, the watchdog on public spending, investigated government procurement in the covid-19 pandemic, looking at a sample of contracts awarded during the emergency. Its report concluded that there were some contracts with "insufficient documentation on key decisions, or how risks such as perceived or actual conflicts of interest have been identified or managed."2

It added, "In addition, a number of contracts were awarded retrospectively, or have not been published in a timely manner. This has diminished public transparency, and the lack of adequate documentation means we cannot give assurance that government has adequately mitigated the increased risks arising from emergency procurement or applied appropriate commercial practices in all cases. While we recognise that these were exceptional circumstances, there are standards that the public sector will always need to apply if it is to maintain public trust.”

Dyer C. Covid-19: Hancock's failure to publish contracts was unlawful. BMJ 2021;372:n511. doi: 10.1136/bmj.n511 pmid: 33608255

2 lacobucci G. Covid-19: Government has spent billions on contracts with little transparency, watchdog says. BMJ2020;371:m4474. doi: 10.1136/bmj.m4474 pmid: 33208349

This article is made freely available for use in accordance with BMJ's website terms and conditions for the duration of the covid-19 pandemic or until otherwise determined by BMJ. You may use, download and print the article for any lawful, non-commercial purpose (including text and data mining) provided that all copyright notices and trade marks are retained. 